\title{
A NEEDLE IN A HAYSTACK? \\ LOCATING THE LEGAL BASIS FOR DETENTION \\ IN NON-INTERNATIONAL ARMED CONFLICT
}

\author{
By Kubo Maćák
}

\section{INTRODUCTION}

April marks the end of winter in the Helmand Province, but mornings can still be bitterly cold. In the early hours of 7 April 2010, however, the weather was the least of Mr. Serdar Mohammed's problems. Before the sky turned to dawn, he was captured in the fields not far from his home by the UK armed forces. Shot at, bitten by an army dog, and finally apprehended, he was brought into UK custody on suspicion of being an insurgent, perhaps even a Taliban commander. He would go on to spend more than 100 days in detention on various British military bases in Afghanistan before being finally handed over to the Afghan authorities. ${ }^{1}$

The case that Mr. Mohammed initiated before the UK courts, Serdar Mohammed v Ministry of Defence, has been much more than a simple dispute over compensation for the alleged unlawful deprivation of liberty. The resulting first-instance ruling was issued in May 2014, a little more than four years after the events that resulted in the claimant's detention. With a degree of English understatement, the judge described it as 'a long judgement which discusses many issues and arguments'. It is, in fact, 117 pages long and covers nearly every question of international law that one can imagine, from the jus ad bellum, to human rights law, IHL, State responsibility, and State immunity. The judge eventually held in favour of the claimant, ruling that his detention after the initial 96 hours violated Article 5 of the European Convention on Human Rights and that he was therefore entitled to compensation. ${ }^{3}$

Crucially, the case revisited an unresolved issue of IHL: does this body of law authorize the detention of persons in non-international armed conflicts ("NIACs")? In other words, does the law of NIAC contain a legal basis for detention? $?^{4}$ The answer to that question could have swayed

\footnotetext{
* Mgr. (Charles); M.Jur.; M.Phil.; D.Phil. (Oxon.); Lecturer in Law at the University of Exeter. I acknowledge with thanks the opportunity to publish a post on the Serdar Mohammed case on the international law blog EJIL: Talk! and the subsequently published responses by Dapo Akande, Lawrence Hill-Cawthorne, and Aurel Sari, which had enabled me to refine my views on some of the matters discussed here. I would also like to thank Yoram Dinstein and Michael N. Schmitt for their helpful comments on an earlier draft of this article. Any remaining errors are my responsibility alone.

${ }^{1}$ Serdar Mohammed v. Ministry of Defence [2014] EWHC 1369 (QB), paras. 8-10.

${ }^{2}$ Ibid., para. 2.

${ }^{3}$ Ibid., paras. 356-357.

${ }^{4}$ Ibid., paras. 232-268.
} 
the pendulum one way or the other. This is because if there was such a legal basis, the UK armed forces could have been justified in holding the claimant for a prolonged period of time for security reasons. Conversely, the finding that IHL does not provide a legal basis for detention in NIACs $^{5}$ led the judge down the road of finally deciding for the claimant and against the Government. ${ }^{6}$

The question of the existence of a legal basis to detain within the law of NIAC is an issue of fundamental importance for the conduct of hostilities in the $21^{\text {st }}$ century, and one which exceeds the confines of any single case. Today, the overwhelming majority of conflicts around the world are NIACs. Like in their international counterparts, parties to NIACs frequently detain persons for security reasons. By definition, at least one of the parties to a NIAC is a non-State actor: an armed group like the Taliban in Afghanistan or the Moro Islamic Liberation Front in the Philippines. Moreover, some of the modern NIACs are so-called 'extraterritorial NIACs' in which an outside State is (or several States are) pitted against an armed group on another State's territory: again, an example being the conflict between a multinational coalition supporting the Afghan Government and various insurgent forces in Afghanistan. ${ }^{7}$ Finally, an international armed conflict (IAC) may evolve into a NIAC, as the Iraqi conflict did after the US-led military coalition withdrew from Iraq. ${ }^{8}$ In all of these situations, locating a legal basis for detention elsewhere than in IHL may be problematic. This is why a close examination of the law of NIAC is necessary.

This article begins with an introduction of the problem of an absence of an express legal basis to detain in the law of NIAC by way of contrasting the provisions regulating detention in IACs and NIACs, respectively. It will consider whether the legal basis for detention in NIACs could be logically inferred either from a putative power to kill in NIACs or from the power to detain in IACs. In the next step, it will consider teleological and practical arguments posed against the existence of a legal basis to detain. Finally, it will put forward a threefold set of reasons which together militate in favour of the legal basis for detention under NIAC.

\section{ABSENCE OF AN EXPRESS LEGAL BASIS TO DETAIN IN THE LAW OF NIAC}

Insofar as international armed conflicts are concerned, the law is enviably clear. Combatants become prisoners of war upon capture ${ }^{9}$ and are subject to internment by the enemy State. ${ }^{10} \mathrm{~A}$ State may intern civilians in its own territory if it is 'absolutely necessary' for its security. ${ }^{11}$ In occupied territories, the internment of civilians is permitted if the Occupying Power considers it 'necessary, for imperative reasons of security'. ${ }^{12}$ What these provisions have in common is that

\footnotetext{
${ }^{5}$ Ibid., para. 268.

${ }^{6}$ Ibid., para. 418.

7 See F. Hampson, “Afghanistan 2001-2010”, International Law and the Classification of Conflicts, 276 (E. Wilmshurst ed., 2012).

8 See Y. Dinstein, Non-International Armed Conflicts in International Law, 57 (2014).

${ }^{9}$ Geneva Convention (III) Relative to the Treatment of Prisoners of War, 1949, 75 U.N.T.S. 135 (hereinafter: "GC III"), Art. 4A.

${ }^{10}$ GC III, supra note 9, Art. 21.

11 Geneva Convention (IV) Relative to the Protection of Civilian Persons in Time of War, 1949, 75 U.N.T.S. 287 (hereinafter: "GC IV"), Art. 42.

12 GC IV, supra note 11, Art. 78.
} 
they establish an express legal basis for internment of a class of persons, without requiring an individualized assessment before depriving anyone of their liberty.

No such express legal basis exists in the treaty law applicable in non-international armed conflicts. To be sure, the law contemplates that detention will take place during such conflicts. Common Article 3 mandates humane treatment and prohibits certain acts with respect to several categories of persons including those placed hors de combat by detention. ${ }^{13}$ Article 5 of Additional Protocol II provides detailed guarantees to 'those deprived of their liberty for reasons related to the armed conflict ${ }^{14}$ and Article 6 of the same instrument encourages amnesty to the same category of people at the end of hostilities. ${ }^{15}$ However, none of these provisions contains an unequivocal authorization to detain in NIACs.

It is conceivable that the parties to a non-international conflict may agree to transpose the legal basis from the law of IAC by way of an ad hoc agreement. ${ }^{16}$ Such 'special agreements', bringing into force specific provisions of the Geneva Conventions are even expressly encouraged by Common Article $3{ }^{17}$ It must, however, be emphasized that the possibility of such agreements does not amount to a systematic response to the problem at the heart of this discussion. They would remain an ad hoc solution for particular conflicts only. What is more, many of the actual agreements entered into by conflict parties in the context of NIACs contain provisions on the treatment of detainees, but do not provide for a specific legal basis for detention. ${ }^{18}$ Thus, even in these situations the problem of the absence of a generally applicable legal basis for detention arises with equal force.

Be that as it may, it would be wrong to infer that the absence of an express authorization automatically means that no legal basis exists under IHL. ${ }^{19}$ International law, as a legal system developed incrementally and on the basis of careful compromise between States as its primary actors, does not always provide clear-cut written legislative solutions for all potential problems that the reality may bring. ${ }^{20}$ It is thus often generally accepted without much controversy that legal basis authorizing specific conduct may be implied from the relevant treaty text ${ }^{21}$ or found in

\footnotetext{
${ }^{13}$ Common Art. 3(1) to the Geneva Conventions.

14 Protocol Additional to the Geneva Conventions of 12 August 1949, and Relating to the Protection of Victims of Non-International Armed Conflicts (Protocol II), 1977, 1125 U.N.T.S. 609 (hereinafter: “AP II”), Art. 5(1).

15 AP II, supra note 14, Art. 6(5).

16 See, e.g., N. V. Amstel, "In Search of Legal Grounds to Detain for Armed Groups", 3 Int'l Humanitarian L. Studies 160, 183-186 (2012).

${ }_{17}$ Common Art. 3(3) to the Geneva Conventions ('The Parties to the conflict should further endeavour to bring into force, by means of special agreements, all or part of the other provisions of the present Convention.').

18 See, e.g., San José Agreement between the Government of El Salvador and the Frente Farabundo Martí para la Liberación Nacional (FMLN) of 26 July 1990 (UN Doc. A/44/971-S/21541), Art. 2; Memorandum of Understanding between Yugoslavia and Croatia of 27 November 1991, reproduced in Marco Sassòli, Antoine A. Bouvier and Anne Quintin, How Does Law Protect in War?, vol. 3 (3rd ed., ICRC 2011) at 111, Arts. 3 and 4.

${ }^{19}$ Cf. Serdar Mohammed, supra note 1, para. 242 ("if CA3 and/or AP2 had been intended to provide a power to detain they would have done so expressly').

20 See also H. J. Morgenthau, Politics Among Nations: The Struggle for Power and Peace (6th ed., 1985) 299, 300 (arguing that vagueness and ambiguity are a frequent feature of international agreements as they allow States to find a common basis on which the different national interests can meet in harmony).

21 See, e.g., Advisory Opinion on Legal Consequences for States of the Continued Presence of South Africa in Namibia (South West Africa) Notwithstanding Security Council Resolution 276 (1970), [1971] I.C.J. Rep., para. 110 (accepting that the legal basis for specific conduct of the Security Council may be implied from the text of the UN Charter); Prosecutor v. Tadic,
} 
customary international law. ${ }^{22}$ To identify the legal basis in this way should be seen as an affirmation of the principle of legality, not as its violation. ${ }^{23}$

The absence of an express legal basis in the Geneva Conventions and their Protocols may in fact be explained more prosaically. The States' representatives at the diplomatic conferences leading to the adoption of these instruments were reluctant to agree on any rules that might be understood as lending a degree of recognition to non-State actors in internal conflicts. ${ }^{24}$ It was for this reason that the Geneva Conventions were limited in their coverage of NIACs to one article only, which was moreover capped with an unambiguous reminder that its application 'shall not affect the legal status of the Parties to the conflict'. ${ }^{25}$ Even more pertinently, all references to 'parties to the conflict' were deleted from the final text of Protocol II at the eleventh hour during the diplomatic conference precisely for fears that the phrase would unacceptably place the entities involved in the conflict on an equal footing. ${ }^{26}$ As we will see below, this does not mean that the drafters did not accept that parties to NIACs would resort to detention or (even less) that they considered detention automatically unlawful. ${ }^{27}$ They were merely reluctant to include any provisions or even formulations which could be 'interpreted in the sense of a recognition of insurgent parties. ${ }^{28}$

\section{LIMITATIONS OF ATTEMPTS TO TRANSPOSE THE LEGAL BASIS FROM OTHER CONTEXTS}

It is sometimes suggested that the power to detain necessarily follows from the power to target individuals. ${ }^{29}$ To some extent, this is logically appealing. Surely if one may lawfully kill an opponent, it must be equally permissible to merely incapacitate her by placing her under detention. However, upon closer inspection, this argument is not as compelling. First of all, it glosses over the fact that not everyone liable to be detained is equally liable to be targeted in the first place. In other words, some individuals may pose a security risk to a party to a conflict

Judgement, Case No. IT-94-1-A (ICTY App. Chamber, 15 July 1999), paras. 185-229 (holding that the legal basis for joint criminal enterprise, a mode of criminal liability, is implied in the text of the ICTY Statute).

22 See, e.g., M. Byers, War Law, 64(2005) (considering that invitation is widely accepted as a legal basis for intervention under customary international law).

${ }^{23}$ Cf. E. Debuf, Captured in War: Lawful Internment in Armed Conflict, 469 (2013) ('an implicit restriction of the right to liberty would flout the principle of legality').

24 See Commentary on the Additional Protocols of 8 June 1977 to the Geneva Conventions of 12 August 1949, 1335, para. 4415 (ICRC, Y. Sandoz, C. Swinarski, \& B. Zimmerman eds., 1987) (hereinafter: “ICRC Commentary”).

${ }^{25}$ Common Art. 3(4) to the Geneva Conventions.

26 See, e.g., Switzerland, Official Records of the Diplomatic Conference on the Reaffirmation and Development of International Humanitarian Law Applicable in Armed Conflicts, Geneva (1974-1977) (Federal Political Department 1978) (hereinafter: "Official Records"), vol. VIII, CDDH/I/SR.40, at 426, para. 29 (Iraq); ibid., vol. VII, CDDH/SR.49, at 65, para. 33 (Saudi Arabia); ibid., CDDH/SR.56, at 219-220, paras. 124-129 (Zaire).

27 See text to notes 82-89 infra.

28 See ICRC Commentary, supra note 24, at 1335, para. 4415.

29 See, e.g., R. Goodman, "The Detention of Civilians in Armed Conflict”, 103 Am. J. Int'l L. 48, 55-56; J. K. Kleffner, "Operational Detention and the Treatment of Detainees", The Handbook of the International Law of Military Operations, 471 (T. D. Gill \& D. Fleck eds., 2010); C. Kreß, "Some Reflections on the International Legal Framework Governing Transnational Armed Conflicts” 15 J. Conflict Security L. 245, 263-264 (2010); S. Sivakumaran, The Law of Non-International Armed Conflict, 301 (2012); Serdar Mohammed, supra note 1, para. 252 (referring to the position of the UK Ministry of Defence). 
without directly participating in the hostilities. With respect to these persons the argument would not suffice.

Secondly and even more crucially, if the legal basis for detention is to be inferred from the law of targeting, one should be able to locate an express legal basis authorizing the killing of individuals in situations of NIAC. However — and again in contrast to the law of IAC $^{30}$ - the applicable treaty law does not contain any such express legal basis. ${ }^{31}$ Instead, it merely protects civilians from being made the object of attack unless they take a direct part in the hostilities. ${ }^{32}$ Therefore, the argument that the power to detain is a corollary of the power to target does not resolve the underlying problem, but merely restates it with equal force in another context. ${ }^{33}$

Somewhat similarly, it can be argued that if it is permissible to detain in IACs, it should logically be permissible to do so in NIACs. ${ }^{34}$ This argument rests on the observation that States have accepted more onerous obligations under the law applicable in IACs than in NIACs. ${ }^{35}$ Because of that, any grant of authority to engage in a particular conduct in IACs should, a fortiori, be seen as affirming their authority to do so in NIACs. ${ }^{36}$ The obvious weakness of this argument is that it only substantiates a legal basis for detention measures taken by the government side to an armed conflict. Any detainees held by a non-State party to the conflict would still be held unlawfully. ${ }^{37}$

Most importantly, the argument's premise itself is not free from doubt either. In particular, it is questionable whether IHL is 'uniformly less restrictive' in NIACs than in IACs. ${ }^{38}$ In fact, there are several areas in which the law of NIAC is more onerous and exacts a greater degree of protection than its counterpart applicable to IACs. ${ }^{39}$ For example, while the law of IAC only prohibits deportation of protected persons from occupied territory, ${ }^{40}$ in NIACs, the prohibition on deportation applies generally to the entire territory affected by the conflict. ${ }^{41}$ It would thus be

\footnotetext{
30 See Protocol Additional to the Geneva Conventions of 12 August 1949, and Relating to the Protection of Victims of International Armed Conflicts (Protocol I), 1977, 1125 U.N.T.S. 3 (hereinafter: “AP I"), Art. 43(2).

31 But see, e.g., ICRC Commentary, supra note 24, at 1453, para. 4789 ("Those who belong to armed forces or armed groups may be attacked at any time.").

32 See AP II, supra note 14, Art. 13(3); see also Common Art. 3(1)(a) to the Geneva Conventions and AP II, supra note 14, Art. 4(2)(a) (prohibiting violence to life and person with respect to persons taking no active part in the hostilities).

33 See, e.g., J. Cerone, "Jurisdiction and Power: The Intersection of Human Rights Law \& the Law of NonInternational Armed Conflict in an Extraterritorial Context" 40 Isr. L. Rev. 396, 411 (2007) (arguing that the law of NIAC does not provide an 'authorization ... to detain or kill) (emphasis added).

34 See Goodman, supra note 29, at 50, 57.

35 Ibid., at 50 .

${ }^{36}$ Ibid.

${ }^{37}$ A possible objection is based on a premise that non-State actors are not bound by the prohibition on arbitrary deprivation of liberty since the latter is a norm that only binds States. If that is the case, the argument goes, armed groups are not acting unlawfully by resorting to detention. Rather, their conduct is normatively neutral from the perspective of international law. However, this approach is potentially even more dangerous. As Somer has warned, it would mean allowing armed groups to detain with impunity, thus further discouraging their compliance with IHL. J. Somer, "Jungle Justice: Passing Sentence on the Equality of Belligerents in Non-international Armed Conflict" 89 Int'l Rev. Red Cross 655, 667-668 (2007).

38 See Goodman, supra note 29, at 50.

39 See further Sivakumaran, supra note 29, at 68-69.

${ }^{40}$ GC IV, supra note 11, Art. 49.

${ }^{41}$ AP II, supra note 14, Art. 17(2).
} 
incorrect to infer the legal basis to detain in NIACs simply on the basis of it being permissible in IACs.

\section{LIMITATIONS OF ARGUMENTS AGAINST A LEGAL BASIS TO DETAIN}

If a legal power to detain cannot be inferred logically from other provisions of IHL, it is necessary to examine whether the law of NIAC can be said to be agnostic with respect to the lawfulness of detention. Accordingly, it could be argued that provisions contemplating detention in NIACs do no more than that - they acknowledge that people will be detained during armed conflicts but do not provide authorization for such detention. This is a compelling argument. After all, the distinction between the jus in bello and the jus ad bellum reflects the fact that IHL as a legal discipline is itself built on agnosticism vis-à-vis the lawfulness of the recourse to force between the conflict parties in the first place. ${ }^{42}$ Although IHL certainly acknowledges that force will be used, it cannot be read as providing any legal authority to do so. ${ }^{43}$ Perhaps the same logic should be applied to the regulation of detention in NIACs. On this view, the law of NIAC is limited in its remit to some of the consequences of the fact of detention, while remaining normatively neutral vis-à-vis that fact itself.

The fundamental problem of this approach is that it potentially leaves a number of situations in which detainees are taken without an available legal basis. It has been suggested that this basis can be found in other applicable bodies of law, in particular in international human rights law ("IHRL"), the domestic law, or in a Security Council resolution. ${ }^{44}$

This suggestion is the least convincing with respect to IHRL. Significant initial hurdles need to be overcome in order to even consider it as a potential solution to the problem at hand. First, it is not clear that the stipulations of this body of law apply equally to States as they do to armed groups; this remains a heavily contested issue at the moment. ${ }^{45}$ Second, given that the rules of IHRL were developed for peacetime, it is potentially problematic to attempt to transpose them into situations of armed violence. ${ }^{46}$

However, even if these two hurdles were surpassed, it would be a misinterpretation to construe the IHRL rules on detention as permissive norms authorizing the deprivation of liberty in particular situations. The tenor of these rules is, in fact, exactly the opposite. IHRL norms probibit detention which does not meet all the requisite conditions linked to the right to security and liberty of a person. Without exception, each applicable instrument includes among these

\footnotetext{
42 See, e.g., Y. Dinstein, The Conduct of Hostilities under the Law of International Armed Conflict (2nd ed., CUP 2010) 3-4.

${ }^{43}$ Lassa Oppenheim, International Law: A Treatise (2nd ed., 1912), vol. II, at 60 ('War is a fact recognised, and with regard to many points regulated, but not established, by International Law.') (emphasis added).

44 See A. S. Deeks, "Administrative Detention in Armed Conflict" (2009) 40 Case Western Reserve Journal of International Law 403, at 404-405 and 413; P. Rowe, "Is There a Right to Detain Civilians by Foreign Armed Forces During a Non-International Armed Conflict?” (2012) 61 ICLQ 697, at 706-709; Debuf, supra note 23, at 488-495.

45 See, e.g., J. M. Henckaerts and C. Wiesener, "Human Rights Obligations of Non-State Armed Groups: A Possible Contribution from Customary International Law?", Research Handbook on Human Rights and Humanitarian Law (R. Kolb and G. Gaggioli eds., 2013), at 146-169.

46 J. Pejić, "Conflict Classification and the Law Applicable to Detention and the Use of Force", International Law and the Classification of Conflicts (E. Wilmshurst, 2012), at 84-85 and 93-94.
} 
conditions the requirement of a legal basis for detention. ${ }^{47}$ IHRL is a restrictive body of law which provides limits on the permissible behaviour of States. ${ }^{48}$ It is incorrect to see it as authorizing detention on its own terms; instead, we need to look elsewhere for a legal basis to ensure that detention is IHRL compliant.

It is true that at times, this legal basis can be found in the applicable domestic law or a Security Council resolution. However, this will often not be sufficient. As the examples of Afghanistan and Yemen show, not all States' legislation contains an applicable legal basis for security internment in times of armed conflict. ${ }^{49}$ Although this could theoretically be remedied by the introduction of emergency legislation providing for such a legal basis, this is often not a realistic prospect in conflicts fought extraterritorially that have come to define our time. Besides, any reliance on domestic law may be unworkable in time of breakdown of order brought about by the internal conflict. Moreover, even if a legal basis of this sort may be found in one of these sources, it will typically only permit detention measures to be taken by one side of the conflict, most likely the territorial government. In all of these situations, IHL thus presents the only remaining plausible legal structure on the basis of which detention may be authorized.

The risk that detention measures would be taken without a legal basis is patently not merely an academic issue. Detention that lacks a legal basis must be considered arbitrary. ${ }^{50}$ The ICJ has described arbitrary detention in the Tehran Hostages case as 'manifestly incompatible with the principles of the Charter of the United Nations' ${ }^{51}$ Arbitrary detention, if committed as part of a widespread or systematic attack directed against a civilian population, may amount to a crime against humanity of imprisonment. ${ }^{52}$ Even when the victim is a single individual, arbitrary detention is a violation of international human rights law provisions on the right to liberty and security of person. ${ }^{53}$ Furthermore, according to the ICRC Study on Customary International

\footnotetext{
47 European Convention for the Protection of Human Rights and Fundamental Freedoms, 1950, 213 U.N.T.S. 211 (hereinafter: "ECHR”), Art. 5(1); International Covenant on Civil and Political Rights, 1966, 999 U.N.T.S. 171 (hereinafter: "ICCPR"), Art. 9(1); American Convention on Human Rights, 1969, 1144 U.N.T.S. 123 (hereinafter: “ACHR”), Art. 7(2); African Charter on Human and Peoples Rights, 1981, 21 I.L.M. 58 (hereinafter: “ACHPR”), Art. 6 .

48 See, e.g., S. Sheeran, "The Relationship of International Human Rights Law and General International Law: Hermeneutic Constraint, or Pushing the Boundaries?”, Routledge Handbook of International Human Rights Law 83 (S. Sheeran \& N. Rodley eds., 2013) (stating that IHRL is based on 'the inherent dignity of the human being and constraint of state or public power') [internal quotation marks omitted].

49 See Serdar Mohammed, supra note 1, para. 75 (holding that Afghan law does not provide 'for detention by foreign armed forces operating in Afghanistan - or for that matter by the Afghan army'); Cable from the US Embassy in Sanaa, Yemen to the US Secretary of State, 8 November 2007, para. 12 ('The lack of strong counterterrorism laws in Yemen means that, even when terrorists are caught, the [government] often lacks the legal basis to hold them.').

50 See Prosecutor v. Gotovina, Judgement, Case No. IT-06-90-T (ICTY Trial Chamber, 15 April 2011), para. 1815 (deprivation of liberty is carried out arbitrarily if there is no legal basis for it); Prosecutor $v$. Stanišic and Zupljanin, Judgement, Case No. IT-08-91-T (ICTY Trial Chamber, 27 March 2013), para. 78 (ditto); see also, e.g., Denizci and others v. Cyprus [2001] European Court of Human Rights (hereinafter: "ECtHR"), paras. 392-393 (the absence of a legal basis for detention amounts to a violation of the right to liberty and security under the ECHR); Medvedyev $v$. France [2010] ECtHR, paras. 102-103 (lack of a legal basis of the requisite quality violates the right to liberty and security under the ECHR).

${ }^{51}$ Case Concerning United States Diplomatic and Consular Staff in Tehran (United States v. Iran), [1980] I.C.J. Rep. 3 , at 42.

${ }^{52}$ Rome Statute of the International Criminal Court, 1998, 37 I.L.M. 999, Art. 7(1)(e); Statute of the International Criminal Tribunal for the Former Yugoslavia, 1993, 32 I.L.M. 1159, Art. 5(e); Statute of the International Criminal Tribunal for Rwanda, 1994, 33 I.L.M. 1598, Art. 3(e).

${ }^{53}$ ECHR, supra note 47, Art. 5(1); ICCPR, supra note 47, Art. 9(1); ACHR, supra note 47, Art. 7(2); ACHPR, supra note 47 , Art. 6.
} 
Humanitarian Law, it is also a violation of customary IHL norms applicable both in IACs and NIACs. ${ }^{54}$ Arbitrary deprivation of liberty thus amounts to unlawful conduct under all of these legal regimes with potentially serious consequences including criminal prosecution.

It is hardly satisfactory to accept that an omnipresent feature of modern-day armed conflicts - which detention surely is - would in fact be unlawful and amount to continuous violations of human rights and other bodies of law. We have thus come full circle. Either we manage to find the legal basis in the apparent normative silence of IHL, or we must bear the overpowering thunder of ubiquitous non-compliance. The former solution would certainly appear to be - as even some opponents admit — motivated by a 'sense of logic'. ${ }^{55}$ After all, as noted above, in addition to other bodies of law, IHL prohibits arbitrary deprivation of liberty too. ${ }^{56}$ It would be illogical for it to prohibit behaviour indispensable for the conduct of hostilities, thereby effectively legally emasculating one or both conflict parties. ${ }^{57}$

However, one should not place much reliance on logic itself. In this respect, Oliver Wendell Holmes's famous aphorism usefully reminds us of the limits of such reasoning: 'The life of the law has not been logic: it has been experience. ${ }^{58}$ In the context of IHL proper, Professor Schmitt similarly notes that 'it would be wrong to assume that IHL - the product of either negotiation between states or pervasive state practice influenced by national interests - is seamless, logical in every circumstance'. ${ }^{59}$ Since logic is a desirable goal, but not the only consideration nor a necessary prerequisite, it is necessary to examine the arguments advanced to justify the no-legalbasis position. It is submitted that if these are found wanting, we may return to the dictates of logic as to a starting point of our inquiry and see if it can be corroborated by other perspectives.

Two arguments-teleological and practical-against the existence of the legal power to detain stand out in the literature and the emerging case-law. According to the first one, the relevant provisions of IHL have a humanitarian purpose and it would be inconsistent with this purpose to interpret them as providing a legal power for detention. ${ }^{60}$ This position's unsaid assumption is that there is something inherently 'antihumanitarian' about detention measures. However, it is not at all certain that such assumption accurately captures the reality of modern-day armed conflicts. At times, security internment measures seem to enhance rather than impede humanitarian aims, such as when they are undertaken in anticipation of a terrorist attack in order to protect the civilian population.

More importantly, humanitarian considerations are but one part of the equation explaining the telos of IHL. The rules of IHL are more fittingly described as being based on 'a dialectical

\footnotetext{
54 See Customary International Humanitarian Law (J. M. Henckaerts \& L. Doswald-Beck eds., 2005) (hereinafter: “CIHLS"), rule 99.

55 Debuf, supra note 23, at 487.

${ }^{56}$ CIHLS, supra note 54, rule 99.

57 See, e.g., ICRC, "Expert Meeting on Procedural Safeguards for Security Detention in Non-International Armed Conflict Experts Report", 2008, at 4 ('The experts agreed that it flows from the practice of armed conflict and the logic of IHL that parties to a conflict may capture persons deemed to pose a serious security threat and that such persons may be interned as long as they continue to pose a threat. Otherwise, the alternatives would be to either release or kill captured persons.') (emphasis added).

58 O. W. Holmes, The Common Law 1(1881).

${ }^{59}$ M. N. Schmitt, "Wound, Capture, or Kill: A Reply to Ryan Goodman's 'The Power to Kill or Capture Enemy Combatants"”, 24 Eur. J. Int'l L. 855, 857.

${ }^{60}$ Debuf, supra note 23, at 466.
} 
compromise between ... two opposing forces': humanity and military necessity. ${ }^{61}$ When analysing the object and purpose of the norms providing safeguards to the detained and interned persons, both of these broader overarching goals should be taken into account. ${ }^{62}$ Once the applicable rules are seen from this perspective, the compatibility of a legal power to detain with the object and purpose of IHL becomes much more apparent. As the US Military Tribunal held in the Hostages case, military necessity 'permits the destruction of life of armed enemies and other persons whose destruction is incidentally unavoidable by the armed conflicts of the war; it allows the capturing of armed enemies and others of peculiar danger ${ }^{6} .{ }^{63}$ It can thus be seen that recourse to a teleological interpretation of the applicable law does not significantly assist the opponents of a legal basis for detention in NIACs.

The second argument focusses on the practical consequences of the absence of an explicit legal basis for detention. According to this position, without such a legal basis, it is impossible to determine 'who may be detained, on what grounds, in accordance with what procedures, or for how long. ${ }^{64}$ It is true that no specific criteria can be found in the text of the applicable treaty law. However, this does not appear to be an insurmountable obstacle, as can be illustrated on the issue of the substantive grounds for detention. ${ }^{65}$

The requisite criteria in this connection can be borrowed from the law of IAC, which provides that persons may be interned if 'absolutely necessary' for the security of the detaining power on its own territory ${ }^{66}$ or for 'imperative reasons of security' in occupied territory. ${ }^{67}$ The ICRC has proposed that the latter standard of 'imperative reasons of security' be co-opted in situations of NIAC' 68 as it 'strikes a workable balance between the need to protect personal liberty and the detaining authority's need to protect against activity seriously prejudicial to its security'. ${ }^{69}$ It is submitted that this is the correct approach. It has been successfully applied in practice, as confirmed by a growing body of international and domestic jurisprudence. ${ }^{70}$ It has also been expressly endorsed as the applicable standard by at least one State. ${ }^{71}$ Finally, it is sufficiently flexible to allow for adjustment on the basis of specific operational reality in a particular conflict.

${ }^{61}$ M. N. Schmitt, "Military Necessity and Humanity in International Humanitarian Law: Preserving the Delicate Balance" 50 Va. J. Int'l L. 795, 798 (2010).

${ }^{62}$ See C. H. B. Garraway, "To Kill or Not to Kill?-Dilemmas on the Use of Force" 14 J. Conflict \& Security L. 499, 501 (2010); see also M. N. Schmitt, "Deconstructing Direct Participation in Hostilities: The Constitutive Elements" 42 Int'l L. \& Politics 697, 713 (2010).

${ }^{63}$ List et al, Judgment (US Military Tribunal, 19 February 1948) 8 L. Rpts. Trials of War Criminals 34, 1253 (1949) (emphasis added).

${ }^{64}$ Serdar Mohammed, supra note 1, para. 246.

${ }^{65}$ For a detailed consideration of the applicable procedural guarantees, see ICRC, Handbook on International Rules Governing Military Operations (ICRC 2013), at 246-251.

${ }^{66}$ See GC IV, supra note 11, Art. 42(1).

${ }^{67}$ See GC IV, supra note 11, Art. 78(1).

68 See ICRC, "Strengthening Legal Protection for Persons deprived of their Liberty in relation to Non-International Armed Conflict", Background Paper, Geneva, (2013), online: https://www.icrc.org/eng/assets/files/2013/strengthening-legal-protection-detention-consultations-2012-2013icrc.pdf, at 13 .

${ }^{69}$ J. Pejić, "The Protective Scope of Common Article 3: More than Meets the Eye" 93 Int'l Rev. Red Cross 189, 209 (2011).

70 See Sivakumaran, supra note 29, at 302 notes 460-461.

71 See United Kingdom, Joint Doctrine Publication 1-10, Captured Persons (CPERS), 1-18, para. 148 (3rd ed., 2015). 
It has been suggested that such transposition of criteria from the law of IAC would flout the principle of legality, which is said to oppose 'any deprivation of liberty by analogy' ${ }^{72}$ However, this position conflates the question of the existence of a legal basis with the question of the substantive grounds for detention. It is submitted that if a legal basis for detention can be found within the law of NIAC, then complementing it with specific criteria from the law of IAC does not undermine but rather strengthens the principle of legality. This is in line with the ICRC's understanding of this principle, according to which the principle requires 'that a person may only be interned or administratively detained on grounds ... set out in national and/or international law' ${ }^{73}$ The criterion of 'imperative reasons of security' is patently found within the established corpus of international law. ${ }^{74}$ Hence, its use in the context of NIAC should not be seen as an impermissible use of analogiam legis in contravention of the principle of legality, but rather as a welcome constraint on the putative broad power to detain appertaining to each conflict party. In other words, the transposition of a workable restrictive standard from the law of IAC fosters the rule of law in NIAC - provided, of course, that a power to detain can indeed be located in the law of NIAC of its own accord. This is a question considered in the next section.

\section{A CASE IN FAVOUR OF A LEGAL BASIS TO DETAIN}

Although it has been said that too much emphasis ought not to be placed on purely logical reasoning due to the specificities of international law, ${ }^{75}$ as a starting point of any legal analysis, the law should be presumed to be internally coherent and logical. ${ }^{76}$ It has been demonstrated that the existence of a legal basis for detention in NIAC is consistent with the requirements of logic as otherwise a frequent and necessary incident of war would have to be perceived as unlawful. It remains to be seen whether there are additional positive reasons supporting the existence of a legal power to detain in the law of NIAC. Three will be examined concerning, in turn, the drafting history of the relevant treaty provisions, the development of customary IHL, and the effectiveness of IHL as a whole.

As an aside, it is important to bear in mind that if there is a legal basis to detain arising from IHL, it must be equally available to all parties to the relevant armed conflicts. This is a consequence of the principle of the equality of the parties to the conflict on which the law of NIAC is based just as much as the law of IAC. ${ }^{77}$ The applicability of this conception of equality of belligerents to the norms governing detention is confirmed by the comments of the drafters after the relevant provisions of Additional Protocol II had been adopted in Committee I during the 1974-77 diplomatic conference. Strikingly, the fact that the rules in question apply equally to all conflict parties was both lauded by the supporters of strict equality of NIAC law like France ${ }^{78}$

\footnotetext{
72 See Debuf, supra note 23, at 473.

73 See ICRC, Handbook on International Rules governing Military Operations (2013), at 247.

74 See GC IV, supra note 11, Art. 78(1).

75 See text to notes 58-59 supra.

76 See further R. Dworkin, Law's Empire, 225-275(1986) (arguing for a conception of law as integrity).

77 See ICRC Commentary, supra note 24, at 1345, para. 4437; Sivakumaran, supra note 29, at 242-243; see also Somer, supra note 37, at 663 (distinguishing the equality of rights and obligations from a general equality of status and emphasizing that the principle of the equality of conflict parties only relates to the former type of equality).

${ }^{78}$ Official Records, supra note 26, vol. VIII, CDDH/I/SR.40, para. 34.
} 
and (begrudgingly) acknowledged by its detractors including Syria ${ }^{79}$ and Iraq. ${ }^{80}$ Therefore, it is submitted that any IHL-based resolution of the question at hand must also be applied equally to all conflict parties. ${ }^{81}$

Firstly, the fact that detention was an indelible part of the conduct of hostilities in NIAC was well understood already at the time of the adoption of Additional Protocol II. ${ }^{82}$ An examination of the travaux préparatoires reveals that States accepted that all parties to the conflicts would resort to detention and internment. During the diplomatic conference held in Geneva, a number of State representatives expressly mentioned detention by non-State actors in connection to the safeguards provided by the eventual Articles 5 and 6 of Protocol II. ${ }^{83}$ Notably, no suggestion was made that such detention would be unlawful or that it would have to be justified on the basis of domestic law. It is safe to assume that the drafters understood that any such requirement would be unrealistic in the conditions of a NIAC.

Later during the conference, the question of the scope of the current Article 5 (ex-Article 8) was discussed. The representative of the United Kingdom, Col. Draper asked the ICRC representative to explain the scope of the provision as its text had been copied over from the original ICRC draft. $^{84}$ Speaking on behalf of the ICRC, Mrs. Bujard replied that the provision 'had been intended to cover all persons whose liberty had been restricted' including 'persons interned without judicial proceedingss. ${ }^{85}$ This explanation was accepted expressly by the Italian representative ${ }^{86}$ and tacitly by the remaining delegates when they adopted the proposed text by consensus and without any objections as to the interpretation advanced by the ICRC. ${ }^{87}$ The ICRC commentary to Article 5 interprets these statements as confirming that the provision covers 'both persons being penally prosecuted and those deprived of their liberty for security reasons, without being prosecuted under penal law'. ${ }^{88}$

Taken together, it is clear that the drafters contemplated detention by all parties to the conflict and were aware of the possibility that a legal basis for such detention would not be forthcoming in domestic law. Admittedly, these statements cannot be taken to amount to an outright recognition of an implicit legal basis to detain under IHL. However, the travaux appear

\footnotetext{
${ }^{79}$ Official Records, supra note 26, vol. VIII, CDDH/I/SR.40, para. 4.

${ }^{80}$ Official Records, supra note 26, vol. VIII, CDDH/I/SR.40, para. 29.

81 See also ICRC, 'Expert Meeting on Procedural Safeguards for Security Detention in Non-International Armed Conflict Experts Report', 4 (2008) ('There was prevailing agreement that any party to a NIAC has an inherent power or "qualified right" to intern persons captured.') (emphasis added).

${ }^{82}$ For a similar point in relation to the 1949 diplomatic conference, see the discussion of the travaux préparatoires in R. Chesney \& J. Goldsmith, "Terrorism and the Convergence of Criminal and Military Detention Models" 60 Stan. L. Rev. 1079, 1086, note 26 (2008) (concluding that drafters 'appeared to assume that military detention would exist in at least some NIACs').

83 See, e.g., Official Records, supra note 26, vol. VIII, CDDH/I/SR.32, para. 71 (Canada) (noting that as the provisions were to apply in a NIAC, 'one of the parties would not be a government and would therefore have only rudimentary facilities at its disposal'); ibid., para. 73 (USSR) (highlighting the importance of the provisions being 'observed by all Parties to the conflict'); ibid., para. 87 (India) (criticising the text of the proposed Art 8 (now Art 5) for the improbability that it would 'be implemented by all the forces concerned').

84 Official Records, supra note 26, vol. VIII, CDDH/I/SR.33, paras. 10-14.

85 Official Records, supra note 26, vol. VIII, CDDH/I/SR.33, para. 17.

86 Official Records, supra note 26, vol. VIII, CDDH/I/SR.33, para. 18.

${ }^{87}$ Official Records, supra note 26, vol. VIII, CDDH/I/SR.39, at 414 (reporting that paras 1(a) and (b) of ex-Art 8 were adopted by consensus).

${ }^{88}$ ICRC Commentary, supra note 24, 1386, para. 4568.
} 
at the very least consistent with the proposition that such a legal basis exists and certainly do not exclude this possibility. ${ }^{89}$

Secondly, the perspective of the development of customary law adds further support in favour of the existence of a legal basis to detain in NIACs. There is plenty of State practice confirming the resort to detention in NIACs by all conflict parties. One study refers to 'numerous examples in which international armed conflict-style detention frameworks have been used during NIAC' in the period between 1949 and 1977, ${ }^{90}$ highlighting in particular the detention of prisoners in Yemen, Algeria, the Congo, and Nigeria. ${ }^{91}$ Another scholar points to extensive State practice, historical as well as modern, to substantiate the claim that States have essentially treated civilian detention as an incident of waging war. ${ }^{92}$ Whatever its theoretical value for the formation of customary rules proper, ${ }^{93}$ there is a wealth of relevant practice on part of non-State armed groups, as well. ${ }^{94}$

In addition to this rich practice, express statements of a corresponding opinio juris appeared recently in particular with respect to detention in extraterritorial NIACs. The leading proponent of the view that detention in NIACs is (implicitly) authorized by IHL is the United States. Already in 2004, the US Supreme Court held in Hamdi that 'the authority to detain for the duration of the relevant conflict' is compatible with 'longstanding law-of-war principles'. ${ }^{95}$ This position was adopted by the US executive which has since referred to it on a number of occasions. ${ }^{96}$ In Hamlily, the US District Court for the District of Columbia accepted the Government's position and held expressly that 'the power to detain ... is consistent with the law of war principles governing non-international conflicts.. ${ }^{97}$

In the context of the Serdar Mohammed case, the Government of the United Kingdom expressly supported the same view, arguing that 'IHL provides a legal basis for detention by UK armed forces' in the context of the NIAC in Afghanistan. ${ }^{98}$ This appears to be a reversal of its

\footnotetext{
89 But see Debuf, supra note 23, at 470 (interpreting the travaux as 'affirm[ing] that the adoption of such a legal basis must be left to the domestic legal order of the State affected by such a conflict'). Regrettably, this interpretation is not substantiated by any direct references to the actual drafting history.

90 See Chesney \& Goldsmith, supra note 82, at 1086.

91 Ibid., at 1087 , note 29.

92 Goodman, supra note 29 , at $57-58$.

93 See, e.g., CIHLS, supra note 54, at xxxvi (considering the legal significance of non-State actors' practice as 'unclear').

94 See Sivakumaran, supra note 29, at 292-305.

${ }^{95}$ Hamdi v. Rumsfeld, 542 US 507 (2004), at 521.

96 See, e.g., United States, Second Periodic Report to the Committee against Torture, 13 January 2006, UN Doc. CAT/C/48/Add.3/Rev.1, submitted 6 May 2005, Annex 1, at 48, para. 1 ('There is no question that under the law of armed conflict, the United States has the authority to detain persons who have engaged in unlawful belligerence until the cessation of hostilities.'); United States, District Court of Colombia, 'Respondents' Memorandum regarding the Government's Detention Authority Relative to Detainees Held at Guantanamo Bay', in re: Guantanamo Bay Detainee Litigation, 13 March 2009, online: http://www.usdoj.gov/opa/documents/memo-re-det-auth.pdf, at 5 ('the United States has the authority to detain those who were part of al-Qaida and Taliban forces' based, inter alia, upon 'long-standing ... law-of-war principles'); United States, Speech by the Legal Adviser, US Department of State, 'The Obama Administration and International Law', given at the Annual Meeting of the American Society of International Law, Washington DC, 25 March 2010 ('As a nation at war, we must comply with the laws of war, but detention of enemy belligerents to prevent them from returning to hostilities is a well-recognized feature of the conduct of armed conflict, as the drafters of Common Article 3 and Additional Protocol II recognized and as our own Supreme Court recognized in Hamdi v. Rumsfeld.').

${ }^{97}$ Hamlily v. Obama, 616 F.Supp.2d 63 (D.D.C. 2009), at 70.

98 See Serdar Mohammed, supra note 1, para. 232.
} 
previously held position ${ }^{99}$ and it was, as stated above, rejected by the court in the first-instance ruling in the case. ${ }^{100}$ Nonetheless, the UK has since updated its Joint Doctrine Publication 1-10 concerning captured persons, which now states that the power to intern civilians in NIAC is is usually derived from a UNSCR, from the Law of Armed Conflict or from host nation law'. ${ }^{101}$ This refined position of the UK Government will likely receive another round of judicial attention in the appellate proceedings in Serdar Mohammed in February 2015. ${ }^{102}$ At the present moment, it may be summarized that the UK Government, like the US, seems to accept that IHL itself may be the source of a legal power to detain in NIAC.

The importance of these statements is underscored by the fact that they relate to conflicts in which alternative sources for a legal power to detain — such as domestic law or a Security Council resolution - were not forthcoming. ${ }^{103}$ Moreover, they have not attracted any protest or denunciation from other members of the international community. Instead, they appear to be consistent with a general trend to no longer see IHL as 'prohibitive law' that it might have been in the early $1950 \mathrm{~s}^{104}$ but at least to some extent as a permissive body of law, authorizing conduct that might otherwise amount to a violation of other norms of international law, particularly human rights law. ${ }^{105}$ As the statements emanate from a limited number of countries, it would be overstating the point to interpret them as confirming in and of themselves the formation of a corresponding customary rule. ${ }^{106}$ The fact that they have not been subsequently controverted, however, adds weight to the contention that the legal basis for detention is in fact inherent to IHL.

Finally, this contention is further strengthened by a concern for the effectiveness of IHL. Few would doubt that the effectiveness of the law is a desirable normative goal in general; ${ }^{107}$ with

\footnotetext{
99 See, e.g., United Kingdom, Joint Doctrine Publication 1-10, Prisoners of War, Internees and Detainees, 2nd ed., May 2006, at 1-7, para. 113(a) (in NIAC, 'power [to detain] may derive from the host state's own domestic law or from a UN Security Council Resolution'); Serdar Mohammed, supra note 1, para. 40, citing UK MOD memorandum dated 1 March 2006 ('there is currently no basis upon which we can legitimately intern ... individuals' who 'pose a substantial and imminent threat to UK forces' in the context of the NIAC in Afghanistan); Serdar Mohammed, supra note 1, para. 44, citing UK MOD memorandum dated June 2008 ('In Afghanistan, however, we cannot replicate Iraq arrangements because UK forces have no power to intern under the extant UNSCR (only a power to temporarily detain is inferred).') (emphasis added).

100 Serdar Mohammed, supra note 1, para. 268.

101 United Kingdom, Joint Doctrine Publication 1-10, Captured Persons (CPERS), 3rd ed., 1-18, para 148 (2015) (emphasis added).

102 See Case Tracker for Civil Appeals, Case Reference A2/2014/1862, online: http://casetracker.justice.gov.uk/.

103 But see Debuf, supra note 23, at 471, note 1534 (listing conflicts in which States relied on domestic legislation to argue against the existence of a legal basis to intern in customary IHL). It is submitted that the relevance of examples such as those given in this work is limited. They do confirm that where an express legal basis is available in domestic law, States may rely on it in relation to their detention practice. Conversely, these examples do not undermine the possibility that the States in question considered their practice equally authorized by IHL.

104 Richard Baxter, 'So-Called Unprivileged Belligerency: Spies, Guerrillas, and Saboteurs' 28 Brit. Y. B. Int'l L. 323, 324 ('The law of war is ... "prohibitive law", in the sense that it forbids rather than authorizes certain manifestations of force.') (internal footnotes omitted).

105 See, e.g., Kreß, supra note 29, 260-261; M. Milanović, "End of Application of International Humanitarian Law", Int'l Rev. Red Cross 26 (forthcoming; online: http://ssrn.com/abstract=2486435) (2015).

106 But see International Law Association (ILA), Statement of Principles Applicable to the Formation of General Customary International Law, 32, para. 16 (2000) (it is not necessary to demonstrate the existence of a belief on the part of the generality of States in order to prove the existence of a corresponding customary rule).

107 See, e.g., G. Lamond, "The Rule of Law”, in The Routledge Companion to Philosophy of Law (A. Marmor ed., 2015), 500 ('For the Rule of Law to prevail in a community, the law must be effective in guiding its subjects.').
} 
respect to IHL, it is even more relevant given the prominence of the duty 'to respect and to ensure respect for' IHL codified in Common Article $1 .{ }^{108}$ To reject the existence of an IHLbased legal power to detain in NIACs would, on balance, diminish the extent to which the norms of IHL are respected by the parties and it would likely lead to abuse. ${ }^{109}$

With respect to armed groups, this outcome is the most evident. Without an available legal basis, any detention practice they would engage in-however operationally necessary it may bewould violate the prohibition on arbitrary deprivation of liberty. ${ }^{110}$ The incentive to abide by IHL will certainly not be strengthened by interpretations insisting that a regular incident of the conduct of hostilities such as detention is unlawful at all times. On the contrary, such interpretation 'makes waging war unrealistic and impossible'.

With respect to States, the effect would admittedly be limited to situations in which there is no alternative legal basis in domestic law or elsewhere. Still, extraterritorial conflicts of the modern age prove that such situations are more than just the subject of academic speculation. As the reactions to the Serdar Mohammed case powerfully illustrate, an interpretation rejecting a legal basis would risk emasculating States engaged in extraterritorial NIACs. ${ }^{112}$ Again, such an outcome would do little for the abidance with the law and, even if accepted, it would likely dissuade States from preferring capture over killing in their conduct of hostilities. ${ }^{113}$

\section{CONCLUSION}

The question of the existence of a legal basis to detain under the law of NIAC is a difficult one. Its analysis shines light into one of the murky corners of the law of armed conflict. That an express legal basis is nowhere to be found is understandable given the asymmetry at the core of any armed conflict between a State and a non-State party. Few States are keen to provide potential insurgents with an explicit written encouragement to set up their own detention facilities in defiance of the legitimate government. Yet this lack of authorizing language may equally turn against the States in situations where detention cannot be justified under any of the other potentially applicable bodies of law, as so aptly demonstrated by the Serdar Mohammed case.

\footnotetext{
${ }^{108}$ Common Art. 1 to the Geneva Conventions. See also R. Ziegler, “Non-Refoulment between 'Common Article 1' and 'Common Article 3"', in Refuge from Inhumanity? War Refugees and International Humanitarian Law (D. Cantor \& J. F. Durieux eds., 2014), 392-396 (arguing that Common Article 1 applies both in IACs and in NIACs).

109 See, e.g., L. Lopez, "Uncivil Wars: The Challenge of Applying International Humanitarian Law to Internal Armed Conflicts" 69 N. Y. U. L. Rev. 916, 935 (1994) (arguing, on the premise of the absence of a legal basis to detain in NIACs, that 'there is nothing that prevents the arbitrary detention of civilians altogether').

110 The result is even more worrying if one were to presume that the prohibition on arbitrary deprivation of liberty only applies to States, and not to non-State actors. As Somer has observed, this interpretation combined with the lack of a legal basis in IHL 'would in fact allow armed opposition groups to detain with impunity'. Somer, supra note 37, at 667-668. This would undermine the respect for the law perhaps even more than the variant considered in the main text.

111 See Van Amstel, supra note 16, at 163.

112 See, e.g., 'Detention ruling shackles troops, says Philip Hammond' Daily Telegraph, 4 May 2014 (reproducing the UK Defence Secretary's reaction to the ruling: 'We cannot send our Armed Forces into battle with both hands tied behind their backs. Our troops ... must be able to detain our enemies who aim to maim and kill UK service personnel and civilians.').

113 See Kreß, supra note 29, at 263.
} 
It should be acknowledged that both potential answers to the main question have their appeal. The position rejecting the existence of a legal power to detain under the valid law of NIAC highlights the ' $\mathrm{H}$ ' in IHL and reminds us of the importance of the humanitarian purpose of the law. ${ }^{114}$ What is more, it can be taken as encouraging further legal development in the sense of finding a comprehensive solution de lege ferenda. It is conceivable that, when combined with the initiatives spearheaded by the ICRC ${ }^{115}$ and others, ${ }^{116}$ in the long run this development could take the shape of a multilateral treaty specifying not only the legal basis, but also other modalities of detention, including substantive grounds and procedural guarantees. ${ }^{117}$ However, for now such an outcome appears unlikely and many States do not hide their reluctance about participating in any further codification projects. ${ }^{118}$ Regrettably, the no-legal-basis position will in many cases simply condone a state of unlawfulness.

It is thus submitted that, on balance, the interpretation that the legal basis for detention in NIAC is inherent in IHL is to be preferred. Although it is accurate to say that this position 'flows from ... the logic of IHL, ${ }^{119}$ it is justified by more than just logical inference. In fact, some of the syllogistic reasoning in favour of this position that had appeared in the literature has been revealed here as unconvincing. ${ }^{120}$ Instead, it is the combination of three practical perspectives which, when taken together, validate the proposed interpretation. First, a close examination of the travaux préparatoires confirms that the existence of an implicit legal basis is consistent with the understandings and expectations of the drafters in 1977. Second, the post-World War II practice and some modern-day pronouncements corroborate the existence of an inherent legal basis in customary IHL. Third, in the light of the challenges posed by modern conflicts marked by the asymmetry of the parties and by the extraterritoriality of the hostilities, the law of NIAC is far more effective if it is interpreted to contain a legal power to detain than when it is not.

\footnotetext{
114 See text to notes 60-63 supra.

115 See J. Pejić, "Procedural Principles and Safeguards for Internment/Administrative Detention in Armed Conflict and Other Situations of Violence" 87 Int'l Rev. Red Cross 375 (2005), adopted as the ICRC's institutional position in 2007: see ICRC, "International Humanitarian Law and the Challenges of Contemporary Armed Conflicts", Report to the 30th International Conference of the Red Cross and Red Crescent, Geneva, (2007), online: https://www.icrc.org/eng/assets/files/2011/30ic-8-4-ihl-challenges-report-annexes-eng-final.pdf, at 11; see further ICRC, Handbook on International Rules governing Military Operations (2013), at 246-251.

116 See, e.g., B. Oswald \& T. Winkler, "The Copenhagen Process: Principles and Guidelines on the Handling of Detainees in International Military Operations”, 83 Nordic J. Int'l L. 128 (2014).

117 Cf. Debuf, supra note 23, at 495-498 (considering the adoption of a multilateral treaty as 'the preferable option' of including a legal basis to detain in the law of NIAC).

118 See, e.g., Statement of Martin Eaton of the UK delegation to the First Periodical Meeting of States Parties to the Geneva Conventions on Humanitarian Law, held in Geneva in January 1998, reproduced in G. Marston, "United Kingdom Materials on International Law 1998”, 69 Brit. Y. B. Int'l L. 433, at 605 (1998) (expressing the continuing doubts of the UK as to whether the adoption of a new instrument would be 'a worthwhile exercise'); see also G. Rose, "Preventive Detention of Individuals Engaged in Transnational Hostilities: Do We Need a Fourth Protocol Additional to the 1949 Geneva Conventions?", New Battlefields/Old Laws: Critical Debates on Asymmetric Warfare 63 (W. Banks ed., 2011) (acknowledging that the adoption of a 'Fourth Protocol ... seems a long-term or unlikely prospect, particularly because of its need for widespread ratification').

119 See ICRC, "Expert Meeting on Procedural Safeguards for Security Detention in Non-International Armed Conflict Experts Report", 4 (2008).

120 See section III supra.
} 